\title{
USABILITY APLIKASI ANDROID HONDA E-CARE DENGAN USE QUESTIONNAIRE DAN IMPORTANCE PERFORMANCE ANALYSIS (IPA)
}

\author{
Kudiantoro Widianto $^{1 凶}$, Tyas Setiyorini², Adityo Surya Prakoso ${ }^{3}$ \\ ${ }^{I}$ Teknologi Informasi, Universitas Bina Sarana Informatika, Jl. Kramat Raya No.98, RT.2/RW.9, \\ Kwitang, Kec. Senen, Kota Jakarta Pusat, Daerah Khusus Ibukota Jakarta, 10450. \\ ${ }^{2}$ Teknik Informatika, STMIK Nusa Mandiri, Jln. Jatiwaringin Raya No.02 Kelurahan Cipinang Melayu, \\ Kec. Makasar, Kota Jakarta Timur, Daerah Khusus Ibukota Jakarta, 13620. \\ ${ }^{3}$ Sistem Informatika, STMIK Nusa Mandiri, Jln. Jatiwaringin Raya No.02 Kelurahan Cipinang Melayu, \\ Kec. Makasar, Kota Jakarta Timur, Daerah Khusus Ibukota Jakarta, 13620. \\ $\otimes_{e-m a i l}:$ kudiantoro.kdw@bsi.ac.id
}

\begin{abstract}
Honda Pondok Pinang, which is located on Jl. Ciputat Raya No.80 Pondok Pinang, South Jakarta, in customer service using an android application called HONDA e-Care. HONDA e-Care is very helpful in making it easier for consumers to access Honda service services. With the Honda e-Care application, customers online carry out ordering services, traffic notification of periodic maintenance schedules, and look on digital to find dealers with the closest distance from the location. But consumers often also get security such as when making an order service but ordering service that is not showing up. Research on the quality of the Honda e-Care application has yet to be carried out. This study aims to measure the usability of the HONDA e-Care android application and provide suggestions for developing the HONDA $e$-Care application in the future. Based on the gap analysis, it was found that in general the use of the HONDA e-Care android application on the Honda Pondok Pinang was not satisfied with the quality of the current applications. With the IPA analysis, the priority scale for improving the quality of the HONDA $e$ Care android application is mapped where quadrant I is the priority scale based on the user's perspective, namely: The HONDA e-Care android application is easy to operate; The search facility on the HONDA eCare android application is functioning properly; The HONDA e-Care android application is easy to download; Image symbols on the HONDA e-Care android application easy implementation; and Access product information on the HONDA e-Care android application is easy to obtain. Managers must increase the four items in order to meet user expectations.
\end{abstract}

Keywords : E-Care, IPA, Usability Aplikasi, Use Questionnaire.

\begin{abstract}
Abstrak
Honda Pondok Pinang yang berlokasi di Jl. Ciputat Raya No.80 Pondok Pinang Jakarta Selatan, dalam pelayanan pelanggan menggunakan aplikasi android dengan nama HONDA e-Care. HONDA e-Care sangat membantu dalam mempermudah konsumen mengakses layanan servis Honda. Dengan aplikasi Honda e-Care pelanggan secara onloine melakukan booking service, lalu mendapatkan notifikasi jadwal perawatan berkala, serta melihat pada peta digital untuk mencari dealer dengan jarak terdekat dari lokasi. Tetapi konsumen sering juga mendapatkan kendala seperti pada saat melakukan booking service tetapi booking service yang sedang berlangsung tidak muncul. Penelitian tentang kualitas dari aplikasi Honda e-Care sampai saat ini belum dilakukan. Penelitian ini bertujuan untuk mengukur sejauh mana usability apalikasi android HONDA e-Care dan memberikan saran buat pengambangan aplikasi HONDA e-Care kedepannya. Berdasarkan analisis gap ditemukan dengan secara umum penggunaan aplikasi android HONDA e-Care pada Honda Pondok Pinang belum puas terhadap kualitas aplikasi yang ada sekarang ini. Dengan analisis IPA, dipetakan skala prioritas peningkatan kualitas aplikasi android HONDA e-Care dimana kuadran I adalah skala prioritas tertinggi berdasarkan perspektif pengguna yaitu: Aplikasi android HONDA e-Care mudah dioperasikan; Fasilitas cari pada aplikasi android HONDA e-Care berfungsi dengan baik; Aplikasi android HONDA e-Care mudah di download; Symbol-simbol gambar pada aplikasi android HONDA e-Care mudah dipahami; dan Akses Informasi produk pada aplikasi android HONDA e-Care mudah diperoleh. Pengelola harus meningkatkan keempat item tersebut dalam memenuhi harapan pengguna.
\end{abstract}

Kata kunci : E-Care, IPA, Usability Aplikasi, Use Questionnaire. 135 


\section{Pendahuluan}

Sekarang ini aplikasi android bukan lagi hal yang baru. Hampir semua kalangan sudah menggunakan aplikasi android. Perusahaan juga banyak yang menggunakan aplikasi android buat baik untuk operasional sehari-hari atau sebagai media promosi dan juga sebagai alat kontrol secara mobile.

Di Indonesia lebih dari 100 juta orang merupakan pengguna aktif smartphone pada tahun 2018 berdasarkan riset emarketer sebagai lembaga riset digital marketing. Urutan ke 4 di dunia yaitu Indonesia setelah Cina, India, dan Amerika[1]. Di dalam smartphone sudah pasti tertanam aplikasi android.

Aplikasi android yang tertanam pada ponsel pintar juga sangat membantu penggunanya dalam hal pencarian informasi dan transaksi online. Perusahaan maupun instansi pemerintah berlomba membuat aplikasi android sebaik mungkin. Fitur yang sesuai dengan tujuannya dan bermanfaat, kualitas yang baik juga tampilan yang menarik akan menarik minat pengguna untuk terus mengakses aplikasi tersebut, selain kemudahan dan pengguna dalam memakai atau menjalankan konten yang ada dalam aplikasi android tersebut. Semuanya itu merupakan aspek yang perlu dalam aplikasi android.

Penelitian yang dilakukan oleh [2] bahwa pengukuran aplikasi sistem pembelajaran di perguruan tinggi maupun sekolah, khususnya di program studi Sistem Informasi Fakultas Teknik UNIPMA dilakukan dengan menggunakan tool Use Questionnaire. Skala likert adalah metode pengukuran yang digunakan untuk menghitung hasil angket. Dari hasil pengukuran tersebut terlihat bahwa penggunaan aplikasi google classroom untuk e-learning di program studi tersebut memiliki nilai usability yang kurang baik.

Aplikasi android dapat dikatakan berkualiatas apabila dilakukan pengujian terhadap fasilitas yang sudah disedikan[3]. Pengujian dilakukan dengan menggunakan Use Questionnaire dan untuk menganalisa datanya digunakan dan analisis kuadran atau Importance Performance Analysis. Dengan penerapan Importance Performance Analysis kinerja kepuasan yang dianggap penting oleh pelanggan dan kinerja kepuasan yang diterima oleh pelanggan dapat diukur. Tujuan utama IPA yaitu sebagai alat mendiagnostik untuk mempermudah identifikasi atributatribut yang berdasar pada kepentingan masing-masing[4].

Honda Pondok Pinang dalam pelayanan pelanggan menggunakan aplikasi android dengan nama HONDA $e$-Care. HONDA e-Care sangat membantu dalam mempermudah konsumen mengakses layanan servis Honda. Booking service dapat dilakukan secara online di dealer Honda, kemudian mendapatkan notifikasi jadwal perawatan berkala, serta mengakses peta secara digital untuk mencari dealer dengan jarak terdekat dari lokasi dengan aplikasi Honda e-Care. Tetapi konsumen sering juga mendapatkan kendala seperti pada saat melakukan booking service tetapi booking service yang sedang berlangsung tidak muncul. Sampai saat ini penelitian tentang kualitas dari aplikasi Honda $e$ Care belum dilakukan.

\section{Metode Penelitian}

\section{A. Tahapan Penelitian}

Tahapan penelitian merupakan tahapantahapan pelaksanaan penelitian dari awal sampai akhir. Masing-masing tahapan diuraikan secara rinci pada gambar 1 .

Berdasarkan proses penelitian di atas dapat dijelaskan tahapan penelitian Usability Aplikasi Android HONDA eCare dengan Use Questionnaire dan Importance Performance Analysis. Tahapan metodologi penelitian dijelaskan secara umum yaitu: 
1. Rumusan Masalah : Menganalisa masalah yang berkaitan dengan Usability Aplikasi Android HONDA e-Care dengan Use Questionnaire dan Importance Performance Analysis

2. Landasan Teori : Mempelajari literatur yang dipakai sebagai kajian teori dalam penelitian ini yang bersumber dari buku, jurnal ilmiah dan informasi di internet yang dapat dipercaya.

\section{Perumusan Hipotesis}

Mengemukakan pernyataan yaitu diduga pengguna aplikasi android HONDA e-Care pada Honda Pondok Pinang belum merasa puas terhadap aplikasi android HONDA $e$-Care yang ada saat ini dan diduga pengguna aplikasi android HONDA $e$-Care pada Honda Pondok Pinang sudah merasa puas terhadap aplikasi android HONDA $e$-Care yang ada saat ini.

4. Pengumpulan Data :

a) Populasi dan Sampel

Berdasarkan populasi yang ada maka ditentukan yang menjadi sample pada penelitian ini. Sample tersebut ditentukan berdasarkan perhitungan dengan rumus slovin :

$$
n=\frac{N}{1+N(e)^{2}}
$$

Keterangan :

$\mathrm{n}$ : ukuran sample

$\mathrm{N}$ : ukuran populasi

e : Persen kelonggaran

ketidaktelitian karena kesalahan pengambilan sampel sebesar $10 \%$

b) Pengembangan Instrumen

Tahapan ini adalah penentuan instrumen penelitian yaitu dengan menggunakan berdasarkan metode Use Questionnaire. Penyusunan kuesioner ini terbagi menjadi dua bagian yaitu identitas sumber data dan kuantitatif dan disebarkan kepada responden.

c) Pengujian Instrumen
Tahap pengujian instrumen dilakukan dengan pengujian prasyarat yaitu menguji tingkat reliabilitas dan validitas pada instrumen yang digunakan pada proses pengumpulan data

5. Analisis Data : Menganalisa hasil pengolahan data dari hasil penelitian dan teori yang berkaitan dengan Importance Performance Analysis.

6. Kesimpulan dan Saran: Menganalisa data dan memerika apakah sesuai dengan maksud dan tujuan penelitian. Memaparkan saran untuk penelitian selanjutnya.

\section{B. Instrumen Penelitian}

Dalam penelitian ini dibutuhkan dua jenis data dimana data tingkat kepentingan (importance) dan tingakat kinerja (performance) dari aplikasi android HONDA e-Care yang ada saat ini yang nantinya akan digunakan untuk analisa. Kuisioner yang diberikan terdiri dari 10 pertanyaan dan dari 10 pertanyaan tersebut telah cukup untuk menunjukkan nilai aspek-aspek usability. Hasil plot kelima aspek usability di atas terhadap 10 pertanyaan kuisioner dapat dilihat pada Tabel 1. Kuesioner Aspek Sistem (System), Tabel 2. Kuesioner Aspek Pengguna (User) dan Tabel 3. Kuesioner Aspek Interaksi (Interaction).

\section{Hasil dan Pembahasan}

\section{A. Data Responden}

Di sini responden diminta untuk memberikan penilaian terhadap indikator yang tersaji dalam pertanyaan-pertanyaan di kuesioner. Pertanyaan dibuat dalan dua jenis yaitu tingkat kepentingan (importance) dan tingkat kinerja (performance). Hasil pengumpulan kuesioner yang berhasil di himpun dan layak di analisis dapat ditunjukan pada Tabel 4. Hasil Pengumpulan Kuesioner

\section{B. Uji Validitas}

Sebelum dilakukan pengujian validitas terlebih dahulu ditentukan taraf nyata $(\alpha)$ 
yaitu 5\% atau 0,05 dan statistik uji yang digunakan adalah (rho-Spearman), Nilai kritis $=$ nilai tabel dimana $n=89 . r$ tabel $=\mathrm{r} \alpha ;(\mathrm{n}-2)=\mathrm{r} 0,05 ;(87)=0,211$

Uji validitas dan reabilitas dilakukan hanya untuk variabel Tingkat Kinerja (Performance).

1. Uji Validitas Tingkat Kepentingan (Importance) Aspek Sistem (System)

Dari hasil uji coba instrumen penelitian pada Tabel 5. Perbandingan Hasil Pengujian $r$ Hitung dengan $r$ Tabel Tingkat Kepentingan Aspek Sistem, terlihat bahwa ke 3 (tiga) item pertanyaan dinyatakan valid maka penelitian ini dilanjutkan.

2. Uji Validitas Tingkat Kepentingan (Importance) Aspek Pengguna (User) Dari hasil uji coba instrumen penelitian pada Tabel 6. Perbandingan Hasil Pengujian $r$ Hitung dengan $r$ Tabel Uji Validitas Tingkat Kepentingan (Importance) Aspek Pengguna (User) terlihat bahwa ke 5 (lima) item pertanyaan dinyatakan valid maka penelitian ini dilanjutkan.

3. Uji Validitas Tingkat Kepentingan (Importance) Aspek Interaksi (Interaction)

Dari hasil uji coba instrumen penelitian pada Tabel 7. Perbandingan Hasil Pengujian $r$ Hitung dengan $r$ Tabel Uji Validitas Tingkat Kepentingan (Importance) Aspek Interaksi (Interaction) terlihat bahwa ke 2 (dua) item pertanyaan dinyatakan valid maka penelitian ini dilanjutkan.
4. Uji Validitas Tingkat Kinerja (Performance) Aspek Sistem (System)

Dari hasil uji coba instrumen penelitian pada Tabel 8. Perbandingan Hasil Pengujian $r$ Hitung dengan $r$ Tabel Uji Validitas Tingkat Kinerja (Performance) Aspek Sistem (System) terlihat bahwa ke 3 (tiga) item pertanyaan dinyatakan valid maka penelitian ini dilanjutkan.
5. Uji Validitas Tingkat Kinerja (Performance) Aspek Pengguna (User)

Dari hasil uji coba instrumen penelitian pada Tabel 9. Perbandingan Hasil Pengujian $r$ Hitung dengan $r$ Tabel Uji Validitas Tingkat Kinerja (Performance) Aspek Pengguna (User) terlihat bahwa ke 5 (lima) item pertanyaan dinyatakan valid maka penelitian ini dilanjutkan.

6. Uji Validitas Tingkat Kinerja (Performance) Aspek Interaksi (Interaction)

Dari hasil uji coba instrumen penelitian pada Tabel 10. Perbandingan Hasil Pengujian $r$ Hitung dengan $r$ Tabel Uji Validitas Tingkat Kinerja (Performance) Aspek Interaksi (Interaction) terlihat bahwa ke 2 (dua) item pertanyaan dinyatakan valid maka penelitian ini dilanjutkan.

\section{Uji Reabilitas}

Dasar keputusan Uji Reliabilitas yaitu jika nilai Croanbach's Alpha $>0.60$ maka kuesioner dinyatakan reliabel atau konsisten. Jika nilai Croanbach's Alpha $<0.60$ maka kuesioner dinyatakan tidak konsisten atau tidak reliabel.

Dari Tabel 11. Perbandingan Hasil Pengujian Reliabilitas Masing-Masing Variabel diketahui nilai alpha untuk Uji Reliabilitas Tingkat Kepentingan (Importance) Aspek Sistem (System) sebesar 0,622, nilai alpha untuk Uji Reliabilitas Tingkat Kepentingan (Importance) Aspek Pengguna (User) sebesar 0,649, nilai alpha untuk Uji Reliabilitas Tingkat Kepentingan (Importance) Aspek Interaksi (Interaction) sebesar 0,710, nilai alpha untuk Hasil Uji Reliabilitas Tingkat Kinerja (Performance) Aspek Sistem (System) sebesar 0,664, nilai alpha Uji Reliabilitas Tingkat Kinerja (Performance) Aspek Pengguna (User) sebesar 0,639, nilai alpha Uji Reliabilitas Tingkat Kinerja (Performance) Aspek Interaksi (Interaction) sebesar 0,729. Semua variabel menunjukkan lebih besar dari $r$ tabel yaitu sebesar 0,60 sehingga semua variabel adalah reliable. 


\section{Analisis Data Dengan Importance Performance Analysis}

Uji reliabilitas dan validitas instrumen penelitian telah dilakukan dan diperoleh hasil instrumen yang reliabel dan valid. Kemudian dilakukan analisa gap antara Kepentingan (Importance) dan Tingkat Kinerja (Performance) pengguna terhadap Aplikasi Android HONDA eCare yang ada saat ini yang ditampilkan pada Tabel 12. Analisa Gap Kepentingan (Importance) dan Tingkat Kinerja (Performance) pengguna terhadap Aplikasi Android HONDA e-Care.

Pada Tabel 12. ditunjukkan bahwa pada kolom Tingkat Kinerja (Performance) lebih rendah dari kolom Tingkat Kepentingan (Importance), oleh karena itu untuk kolom skor kepuasan digunakan rumus Tingkat Kinerja (Performance) Tingkat Kepentingan (Importance) $=$ Skor Kepuasan. Rumus tesebut digunakan pada kolom skor kepuasan sehingga terlihat bahwa nilai pada kolom tersebut bernilai negatif, yang berarti bahwa semua variable yang diuji pada responden belum memenuhi harapan responden. Dalam arti lain secara umum pengguna belum merasa puas terhadap kinerja aplikasi HONDA e-Care yang ada sekarang ini. Ada banyak hal yang terkait kualitas aplikasi android HONDA e-Care yang harus ditingkatkan.

Dalam mengetahui skala prioritas perbaikan pada aplikasi android HONDA e-Care dilakukan analisis lanjutan dengan Importance Performance Analysis yaitu item yang ada terbagi menjadi empat kuadran yang dipetakan ke dalam grafik Importance Performance Analysis seperti pada Gambar 2.

Berdasarkan hasil pada Gambar 2. terlihat bahwa semua item telah dipetakan ke dalam empat kuadran dengan skala prioritas sebagai berikut :

1. Kuadran I : Item yang termasuk dalam kuadran ini merupakan prioritas utama peningkatan kualitas aplikasi android HONDA e-Care yakni terdiri dari: [2] Aplikasi android HONDA e-Care mudah dioperasikan; [5] Fasilitas cari pada aplikasi android HONDA e-Care berfungsi dengan baik; [7] Aplikasi android HONDA eCare mudah di download; [8] Symbol-simbol gambar pada aplikasi android HONDA e-Care mudah dipahami; [9] Akses Informasi produk pada aplikasi android HONDA e-Care mudah diperoleh.

Kelima item ([2], [5], [7], [8], [9]) merupakan area yang penting berdasarkan persepsi pengguna aplikasi android HONDA e-Care tetapi belum memenuhi harapan pengguna sehingga perlu diperbaiki supaya memenuhi harapan pengguna.

2. Kuadran II : Item yang termasuk dalam kuadran ini merupakan prestasi atau keunggulan aplikasi android HONDA e-Care yang harus dipertahankan karena telah memenuhi harapan pengguna yaitu : [1] Tampilan aplikasi android HONDA e-Care mudah dikenali; [3] Kombinasi warna aplikasi android HONDA e-Care enak dilihat.

Kedua item ([1], [3]) merupakan area yang penting menurut persepsi pengguna aplikasi android HONDA e-Care dan dianggap telah memenuhi ekspektasi pengguna.

3. Kuadran III : Item yang termasuk dalam kuadran ini merupakan skala prioritas yang rendah bagi pengelola aplikasi android HONDA e-Care karena tidak dianggap penting oleh pengguna yaitu : [4] Tampilan menu pada aplikasi android HONDA eCare mudah dikenali; [6] Aplikasi android HONDA e-Care mudah dibaca; [10] Aplikasi android HONDA e-Care sesuai kebutuhan Ketiga item ([4], [6], [10]) merupakan area yang oleh pengguna dianggap tidak penting oleh karena itu prioritasnya rendah dan dapat diabaikan oleh pengelola. 
4. Kuadran IV : Item dalam kuadran ini adalah area yang dianggap berlebihan karena oleh pengguna dianggap tidak penting namun persepsi atau kinerjanya tinggi, tetapi pada area ini tidak ditemukan.

\section{KESIMPULAN}

Nilai alpha untuk Uji Reliabilitas Tingkat Kepentingan (Importance) Aspek Sistem (System) sebesar 0,622, nilai alpha untuk Uji Reliabilitas Tingkat Kepentingan (Importance) Aspek Pengguna (User) sebesar 0,649, nilai alpha untuk Uji Reliabilitas Tingkat Kepentingan (Importance) Aspek Interaksi (Interaction) sebesar 0,710, nilai alpha untuk Hasil Uji Reliabilitas Tingkat Kinerja (Performance) Aspek Sistem (System) sebesar 0,664, nilai alpha Uji Reliabilitas Tingkat Kinerja (Performance) Aspek Pengguna (User) sebesar 0,639, nilai alpha Uji Reliabilitas Tingkat Kinerja (Performance) Aspek Interaksi (Interaction) sebesar 0,729. Seluruh variabel menampilkan nilai yang lebih besar dari $r$ tabel yaitu sebesar 0,60 sehingga seluruh variabel adalah Reliable. Dari hasil analisis gap ditemukan bahwa pengguna secara umum belum merasa puas dengan kinerja aplikasi android HONDA e-Care yang ada sekarang ini. Banyak hal yang berkaitan dengan kualitas aplikasi android HONDA e-Care yang harus ditingkatkan. Dari hasil analisis IPA dapat dipetakan skala prioritas peningkatan kualitas aplikasi android HONDA e-Care di mana kuadran I merupakan skala prioritas tertinggi berdasarkan perspektif pengguna yaitu: Aplikasi android HONDA e-Care mudah dioperasikan; Fasilitas cari pada aplikasi android HONDA e-Care berfungsi dengan baik; Aplikasi android HONDA e-Care mudah di download; Symbolsimbol gambar pada aplikasi android HONDA e-Care mudah dipahami; dan Akses Informasi produk pada aplikasi android HONDA e-Care mudah diperoleh. Pengelola harus segera meningkatkan kelima item tersebut untuk memenuhi harapan pengguna. Area yang merupakan prestasi atau keunggulan aplikasi android HONDA e-Care yang harus dipertahankan terletak pada kuadran II yaitu: Tampilan aplikasi android HONDA e-Care mudah dikenali dan Kombinasi warna aplikasi android HONDA e-Care enak dilihat.

Dari penjelasan diatas dapat disimpulkan secara umum aplikasi android HONDA e-Care harus diperbaiki ini menunjukkan bahwa hipotesa $\mathrm{H} 0$ diterima dan $\mathrm{H} 1$ ditolak.

\section{Ucapan Terima kasih}

Penelitian ini untuk HONDA e-Care oleh STMIK Nusa Mandiri melalui kegiatan penelitian.

\section{Daftar Pustaka}

[1] I. Rahmayani, "Indonesia Raksasa Teknologi Digital Asia," https://kominfo.go.id, 2015. .

[2] N. Asnawi, "Pengukuran Usability Aplikasi Google Classroom Sebagai E-learning Menggunakan USE Questionnaire (Studi Kasus: Prodi Sistem Informasi UNIPMA)," Res. Comput. Inf. Syst. Technol. Manag., vol. 1, no. 01, p. 17, 2018.

[3] B. O. Lubis, A. Salim, and Jefi, "EVALUASI USABILITY SISTEM APLIKASI MOBILE JKN MENGGUNAKAN USE QUESTIONNAIRE," J. Saintekom, vol. 10, no. 1, pp. 65-76, 2020.

[4] N. Q. Andika, D. Cahya, and P. Buani, "Perancangan Sistem Informasi Perpustakaan Studi Kasus: SMK YPK - Kesatuan Jakarta," Simnasiptek, pp. 153-154, 2017.

[5] Sugiyono, Metode Penelitian Kuantitatif, Kualitatif, dan $R \& D$. Bandung: Alfabeta, 2016. 


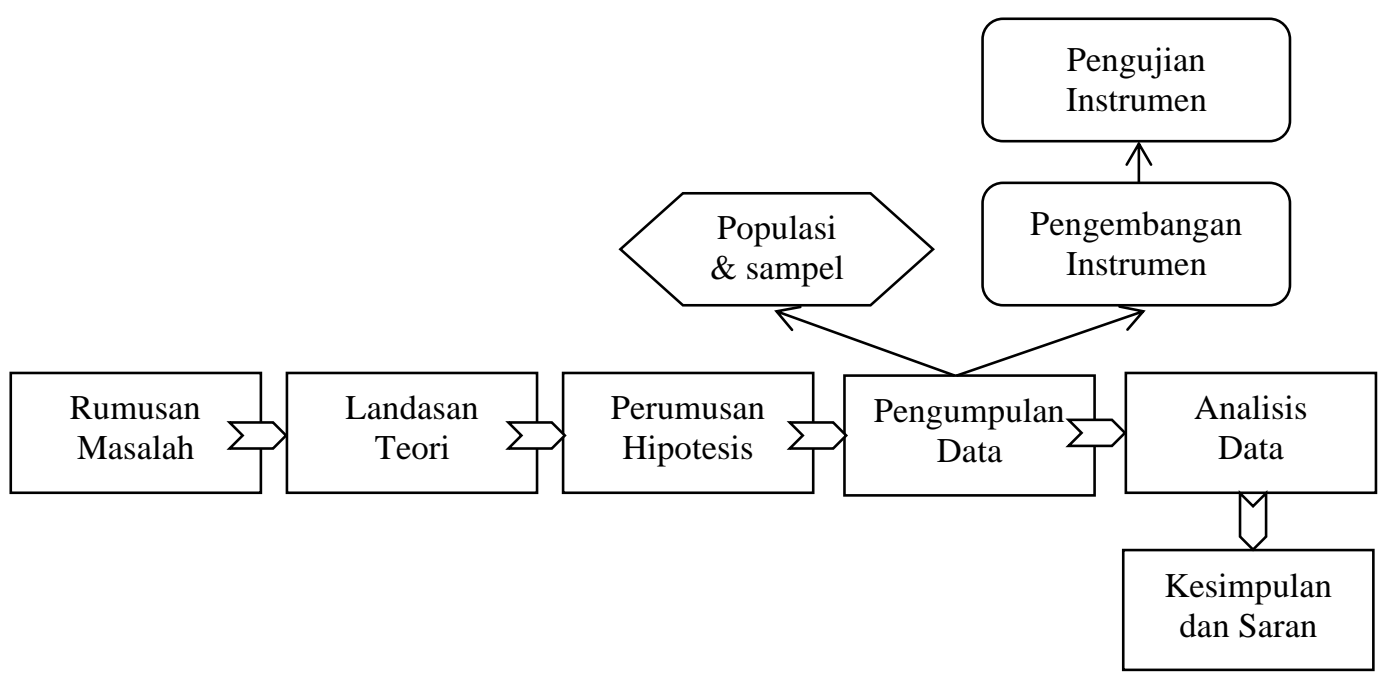

Sumber: [5]

Gambar 1. Tahapan Penelitian

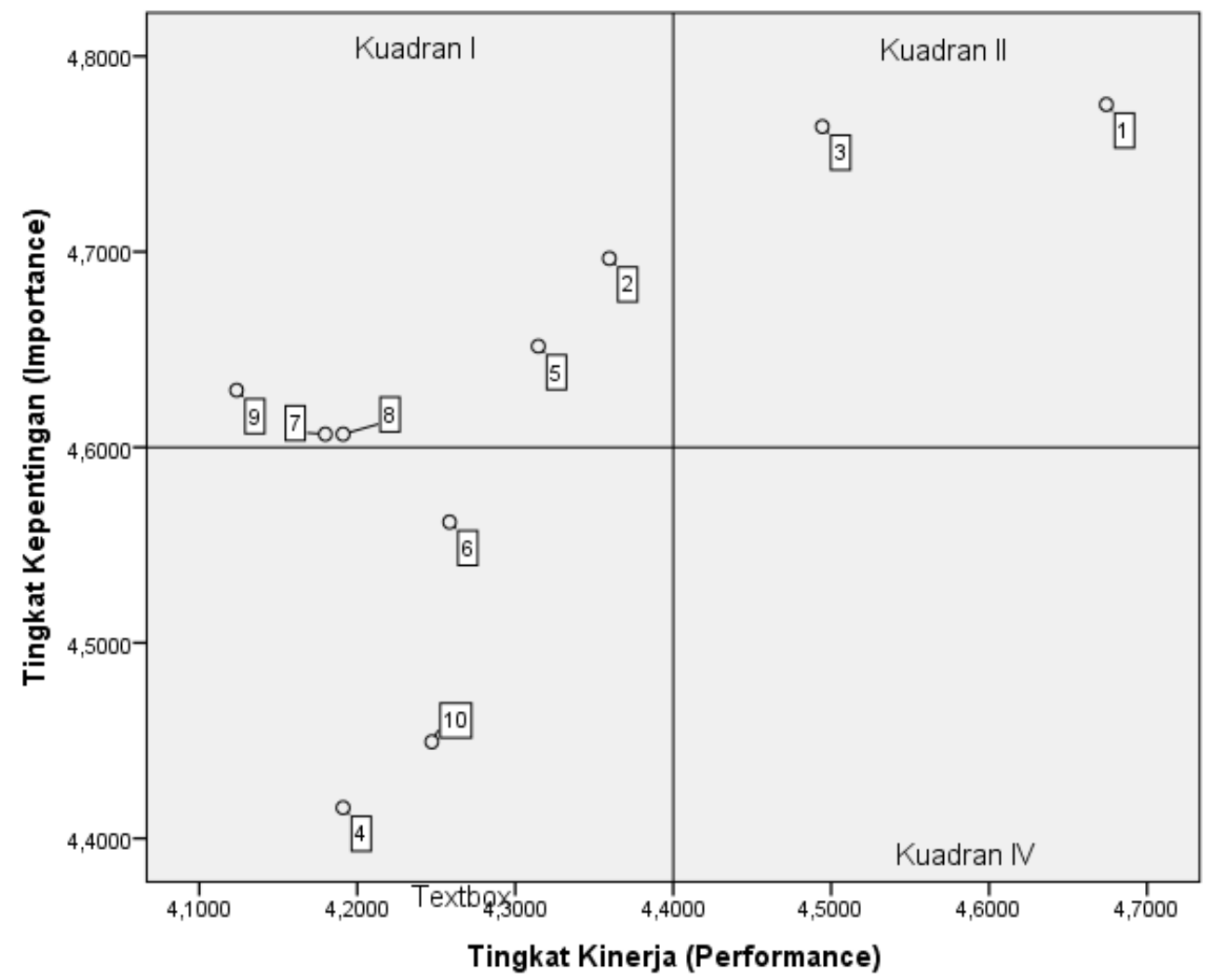

Gambar 2. Grafik IPA Hasil Pemetaan 
Kudiantoro Widianto, dkk., Usability Aplikasi ...

Tabel 1. Kuesioner Aspek Sistem (System)

\begin{tabular}{|c|c|c|c|c|c|c|c|c|c|c|c|}
\hline \multirow[t]{4}{*}{ No } & \multirow{2}{*}{\multicolumn{5}{|c|}{$\begin{array}{c}\text { Tingkat Kepentingan } \\
\text { (Importance) }\end{array}$}} & \multirow{4}{*}{ Aspek Sistem (System) } & \multicolumn{5}{|c|}{ Tingkat Kinerja (Performance) } \\
\hline & & & & & & & \multicolumn{5}{|c|}{ Alternatif Jawaban } \\
\hline & STP & TP & CP & $\mathbf{P}$ & SP & & STB & TB & CB & B & SB \\
\hline & 1 & 2 & 3 & 4 & 5 & & 1 & 2 & 3 & 4 & 5 \\
\hline 1 & & & & & & $\begin{array}{c}\text { Tampilan aplikasi android } \\
\text { HONDA } e \text {-care mudah dikenali }\end{array}$ & & & & & \\
\hline 2 & & & & & & $\begin{array}{l}\text { Tampilan aplikasi android } \\
\text { HONDA } e \text {-Care mudah } \\
\text { dioperasikan }\end{array}$ & & & & & \\
\hline 3 & & & & & & $\begin{array}{c}\text { Kombinasi warna aplikasi } \\
\text { android HONDA e-care enak } \\
\text { dilihat }\end{array}$ & & & & & \\
\hline
\end{tabular}

Tabel 2. Kuesioner Aspek Pengguna (User)

\begin{tabular}{|c|c|c|c|c|c|c|c|c|c|c|c|}
\hline \multirow[t]{4}{*}{ No } & & $\begin{array}{r}\text { igkat } \\
(\mathrm{Im})\end{array}$ & $\begin{array}{l}\text { epen } \\
\text { rtanc }\end{array}$ & igan & & \multirow{4}{*}{ Aspek Pengguna (User) } & \multicolumn{5}{|c|}{ Tingkat Kinerja (Performance) } \\
\hline & \multicolumn{5}{|c|}{ Alternatif Jawaban } & & \multicolumn{5}{|c|}{ Alternatif Jawaban } \\
\hline & STP & $\mathbf{T P}$ & $\mathbf{C P}$ & $\mathbf{P}$ & SP & & STB & TB & CB & B & SB \\
\hline & 1 & 2 & 3 & 4 & 5 & & 1 & 2 & 3 & 4 & 5 \\
\hline 1 & & & & & & $\begin{array}{c}\text { Tampilan menu pada aplikasi } \\
\text { android HONDA } e \text {-care mudah } \\
\text { dikenali }\end{array}$ & & & & & \\
\hline 2 & & & & & & $\begin{array}{c}\text { Fasilitas cari pada aplikasi } \\
\text { android HONDA } e \text {-Care } \\
\text { berfungsi dengan baik }\end{array}$ & & & & & \\
\hline 3 & & & & & & $\begin{array}{l}\text { Aplikasi android HONDA } e \text {-Care } \\
\text { mudah dibaca }\end{array}$ & & & & & \\
\hline 4 & & & & & & $\begin{array}{l}\text { Aplikasi android HONDA e-Care } \\
\text { mudah di download }\end{array}$ & & & & & \\
\hline 5 & & & & & & $\begin{array}{l}\text { SImbol-simbol gambar pada } \\
\text { aplikasi android HONDA } e \text {-Care } \\
\text { mudah dipahami }\end{array}$ & & & & & \\
\hline
\end{tabular}

Tabel 3. Kuesioner Aspek Interaksi (Interaction)

\begin{tabular}{|c|c|c|c|c|c|c|c|c|c|c|c|}
\hline \multirow[t]{4}{*}{ No } & & $\begin{aligned} \text { gikat } \\
(I m)\end{aligned}$ & $\begin{array}{l}\text { epen } \\
\text { rtanc }\end{array}$ & nga & & \multirow{4}{*}{ Aspek Pengguna (User) } & \multicolumn{5}{|c|}{ Tingkat Kinerja (Performance) } \\
\hline & \multicolumn{5}{|c|}{ Alternatif Jawaban } & & \multicolumn{5}{|c|}{ Alternatif Jawaban } \\
\hline & STP & $\mathbf{T P}$ & CP & $\mathbf{P}$ & SP & & STB & TB & CB & B & SB \\
\hline & 1 & 2 & 3 & 4 & 5 & & 1 & 2 & 3 & 4 & 5 \\
\hline 1 & & & & & & $\begin{array}{l}\text { Akses informasi produk pada } \\
\text { aplikasi android HONDA } \text {-Care } \\
\text { mudah diperoleh }\end{array}$ & & & & & \\
\hline 2 & & & & & & $\begin{array}{l}\text { Aplikasi android HONDA e-Care } \\
\text { sesuai kebutuhan }\end{array}$ & & & & & \\
\hline
\end{tabular}

Tabel 4. Hasil Pengumpulan Kuesioner

\begin{tabular}{cccc}
\hline No & $\begin{array}{c}\text { Jumlah } \\
\text { Kuesioner }\end{array}$ & $\begin{array}{c}\text { Persentase } \\
\text { Kuesioner }\end{array}$ & Keterangan Kuesioner \\
\hline 1. & 89 & $100 \%$ & Kuesioner yang pengisiannya lengkap \\
\hline 2. & 0 & $0 \%$ & Kuesioner yang pengisiannya tidak lengkap \\
\hline 3. & 0 & $0 \%$ & Kuesioner yang tidak memenuhi syarat \\
\hline
\end{tabular}

Tabel 5. Perbandingan Hasil Pengujian r Hitung dengan r Tabel Tingkat Kepentingan Aspek Sistem

\begin{tabular}{cccc}
\hline Variabel & $\begin{array}{c}\mathbf{r} \\
\text { Hitung }\end{array}$ & $\begin{array}{c}\mathbf{r} \\
\text { Tabel }\end{array}$ & Keputusan \\
\hline Kepentingan_X11 & 0,732 & 0,211 & Valid \\
\hline Kepentingan_X12 & 0,805 & 0,211 & Valid \\
\hline Kepentingan_X13 & 0,725 & 0,211 & Valid \\
\hline
\end{tabular}


Tabel 6. Perbandingan Hasil Pengujian r Hitung dengan $r$ Tabel Uji Validitas Tingkat Kepentingan (Importance) Aspek Pengguna (User)

\begin{tabular}{cccl}
\hline Variabel & $\begin{array}{c}\mathbf{r} \\
\text { Hitung }\end{array}$ & $\begin{array}{c}\text { T } \\
\text { Tabel }\end{array}$ & Keputusan \\
\hline Kepentingan_X21 & 0,736 & 0,211 & Valid \\
\hline Kepentingan_X22 & 0,408 & 0,211 & Valid \\
\hline Kepentingan_X23 & 0,802 & 0,211 & Valid \\
\hline Kepentingan_X24 & 0,619 & 0,211 & Valid \\
\hline Kepentingan_X25 & 0,624 & 0,211 & Valid \\
\hline
\end{tabular}

Tabel 7. Perbandingan Hasil Pengujian r Hitung dengan $r$ Tabel Uji Validitas Tingkat Kepentingan (Importance) Aspek Interaksi (Interaction)

\begin{tabular}{cccc}
\hline Variabel & $\begin{array}{c}\mathbf{r} \\
\text { Hitung }\end{array}$ & $\begin{array}{c}\text { r } \\
\text { Tabel }\end{array}$ & Keputusan \\
\hline Kepentingan_X31 & 0,898 & 0,211 & Valid \\
\hline Kepentingan_X32 & 0,864 & 0,211 & Valid \\
\hline
\end{tabular}

Tabel 8. Perbandingan Hasil Pengujian r Hitung dengan r Tabel Uji Validitas Tingkat Kinerja (Performance) Aspek Sistem (System)

\begin{tabular}{cccc}
\hline Variabel & $\begin{array}{c}\mathbf{r} \\
\text { Hitung }\end{array}$ & $\begin{array}{c}\text { r } \\
\text { Tabel }\end{array}$ & Keputusan \\
\hline Kinerja_Y11 & 0,749 & 0,211 & Valid \\
\hline Kinerja_Y12 & 0,778 & 0,211 & Valid \\
\hline Kinerja_Y13 & 0,799 & 0,211 & Valid \\
\hline
\end{tabular}

Tabel 9. Perbandingan Hasil Pengujian r Hitung dengan r Tabel Uji Validitas Tingkat Kinerja (Performance) Aspek Pengguna (User)

\begin{tabular}{cccc}
\hline Variabel & $\begin{array}{c}\mathbf{r} \\
\text { Hitung }\end{array}$ & $\begin{array}{c}\mathbf{r} \\
\text { Tabel }\end{array}$ & Keputusan \\
\hline Kinerja_Y21 & 0,748 & 0,211 & Valid \\
\hline Kinerja_Y22 & 0,762 & 0,211 & Valid \\
\hline Kinerja_Y23 & 0,616 & 0,211 & Valid \\
\hline Kinerja_Y24 & 0,555 & 0,211 & Valid \\
\hline Kinerja_Y25 & 0,527 & 0,211 & Valid \\
\hline
\end{tabular}

Tabel 10. Perbandingan Hasil Pengujian r Hitung dengan $r$ Tabel Uji Validitas Tingkat Kinerja (Performance) Aspek Interaksi (Interaction)

\begin{tabular}{cccc}
\hline Variabel & $\begin{array}{c}\mathbf{r} \\
\text { Hitung }\end{array}$ & $\begin{array}{c}\mathbf{r} \\
\text { Tabel }\end{array}$ & Keputusan \\
\hline Kepentingan_X31 & 0,893 & 0,211 & Valid \\
\hline Kepentingan_X32 & 0,881 & 0,211 & Valid \\
\hline
\end{tabular}

Tabel 11. Perbandingan Hasil Pengujian Reliabilitas Masing-Masing Variabel

\begin{tabular}{cccc}
\hline Variabel & $\begin{array}{c}\text { Nilai } \\
\text { Croanbach's } \\
\text { Alpha }\end{array}$ & $\begin{array}{c}\mathbf{r} \\
\text { Tabel }\end{array}$ & Keterangan \\
\hline $\begin{array}{c}\text { Tingkat Kepentingan (Importance) Aspek } \\
\text { Sistem (System) }\end{array}$ & 0,622 & 0,60 & Reliable \\
\hline $\begin{array}{c}\text { Tingkat Kepentingan (Importance) Aspek } \\
\text { Pengguna (User) }\end{array}$ & 0,649 & 0,60 & Reliable \\
\hline
\end{tabular}


Kudiantoro Widianto, dkk., Usability Aplikasi ...

\begin{tabular}{cccc}
\hline $\begin{array}{c}\text { Tingkat Kepentingan (Importance) Aspek } \\
\text { Interaksi (Interaction) }\end{array}$ & 0,710 & 0,60 & Reliable \\
\hline $\begin{array}{c}\text { Tingkat Kinerja (Performance) Aspek Sistem } \\
\text { (System) }\end{array}$ & 0,664 & 0,60 & Reliable \\
\hline $\begin{array}{c}\text { Tingkat Kinerja (Performance) Aspek } \\
\text { Pengguna (User) }\end{array}$ & 0,639 & 0,60 & Reliable \\
\hline $\begin{array}{c}\text { Tingkat Kinerja (Performance) Aspek Interaksi } \\
\text { (Interaction) }\end{array}$ & 0,729 & 0,60 & Reliable \\
\hline
\end{tabular}

Tabel 12. Analisa Gap Kepentingan (Importance) dan Tingkat Kinerja (Performance) pengguna terhadap Aplikasi Android HONDA e-Care

\begin{tabular}{|c|c|c|c|c|}
\hline No & Variabel Yang di Ukur & $\begin{array}{l}\text { Tingkat } \\
\text { Kepentingan } \\
\text { (Importance) }\end{array}$ & $\begin{array}{l}\text { Tingkat Kinerja } \\
\text { (Performance) }\end{array}$ & $\begin{array}{c}\text { Skor } \\
\text { Kepuasan }\end{array}$ \\
\hline \multicolumn{5}{|c|}{ Aspek Sistem (System) } \\
\hline 1. & $\begin{array}{c}\text { Tampilan aplikasi android } \\
\text { HONDA e-Care mudah } \\
\text { dikenali }\end{array}$ & 4,7753 & 4,6742 & $-0,1011$ \\
\hline 2. & $\begin{array}{l}\text { Aplikasi android HONDA e- } \\
\text { Care mudah dioperasikan }\end{array}$ & 4,6966 & 4,3596 & $-0,3371$ \\
\hline 3. & $\begin{array}{l}\text { Kombinasi warna aplikasi } \\
\text { android HONDA e-Care enak } \\
\text { dilihat }\end{array}$ & 4,7640 & 4,4944 & $-0,2697$ \\
\hline \multicolumn{5}{|c|}{ Aspek Pengguna (User) } \\
\hline 4. & $\begin{array}{c}\text { Tampilan menu pada aplikasi } \\
\text { android HONDA e-Care } \\
\text { mudah dikenali }\end{array}$ & 4,4157 & 4,1910 & $-0,2247$ \\
\hline 5. & $\begin{array}{l}\text { Fasilitas cari pada aplikasi } \\
\text { android HONDA e-Care } \\
\text { berfungsi dengan baik }\end{array}$ & 4,6517 & 4,3146 & $-0,3371$ \\
\hline 6. & $\begin{array}{l}\text { Aplikasi android HONDA e- } \\
\text { Care mudah dibaca }\end{array}$ & 4,5618 & 4,2584 & $-0,3034$ \\
\hline 7. & $\begin{array}{l}\text { Aplikasi android HONDA e- } \\
\text { Care mudah di download }\end{array}$ & 4,6067 & 4,1798 & $-0,4270$ \\
\hline 8. & $\begin{array}{l}\text { Symbol-simbol gambar pada } \\
\text { aplikasi android HONDA e- } \\
\text { Care mudah dipahami }\end{array}$ & 4,6067 & 4,1910 & $-0,4157$ \\
\hline \multicolumn{5}{|c|}{ Aspek Interaksi (Interaction) } \\
\hline 9. & $\begin{array}{l}\text { Akses Informasi produk pada } \\
\text { aplikasi android HONDA e- } \\
\text { Care mudah diperoleh }\end{array}$ & 4,6292 & 4,1236 & $-0,5056$ \\
\hline 10 & $\begin{array}{l}\text { Aplikasi android HONDA e- } \\
\text { Care sesuai kebutuhan }\end{array}$ & 4,4494 & 4,2472 & $-0,2022$ \\
\hline
\end{tabular}

